УДК 336.14: 347.73

Вавдіюк Н.С., д.е.н., професор

Завідувач кафедри менеджменту

Vavdiiuk N., Doctor of Economics Science, Professor

Head of Management Department https://orcid.org/0000-0001-9100-3722

\title{
УПРАВЛІННЯ БЮДЖЕТНИМИ ПОРУШЕННЯМИ В РЕГІОНАХ УКРАЇНИ
}

\author{
Луцький національний технічний університет
}

Здійснено аналіз рівня бюджетних порушень, подано оцінку ефективності управління бюджетними порушеннями. Сформовано гіпотезу оцінки управління бюджетними порушеннями, зміст якої полягає в тому, що непряма оцінка ефективності управління бюджетними порушеннями дозволяє здійснити порівняння щодо встановлених та відшкодованих сум матеріальних збитків у грошовому вимірі. У 2019 році на 502 об'єктах контролю Держаудитслужби виявлено недоотримання фінансових ресурсів бюджетами на загальну суму 215,9 млн грн, а у 2018 році - понад 305,8 млн грн державного бюджету на суму більш понад 46,7 млн грн, (у 2018 році - 36,9 млн грн) та з місцевих бюджетів понад 47,2 млн грн (у 2018 році - 22,9 млн грн). У 2019 році забезпечено надходження недоотриманих фінансових ресурсів бюджетів всіх рівнів у обсязі 108,7 млн грн. Розраховано значення індексу ефективності управління бюджетними правопорушеннями із встановлення та відшкодування матеріальних збитків показує скільки у грошовому вимірі відшкодованих збитків припадає на 1 грн встановлених матеріальних збитків. У межах прав та наданих повноважень органами Держаудитслужби у 2019 році забезпечено відшкодування і поновлення незаконних, нецільових витрат та недостач фінансових і матеріальних ресурсів на загальну суму майже 466,6 млн грн, що становить 63,27\% від виявлених таких бюджетних порушень. управління.

Ключові слова: фінансові порушення, часовий лаг фінансових правопорушень, ефективність

\section{MANAGEMENT OF BUDGET VIOLATIONS IN THE REGIONS OF UKRAINE}

\section{Lutsk National Technical University}

The level of budget violations is analyzed, the efficiency of budget violations management is assessed. The hypothesis of the assessment of budget violations management is formed, the content of which is that the indirect assessment of the effectiveness of budget violations management allows to make a comparison of the established and reimbursed amounts of material losses in monetary terms. In 2019, 502 objects of control of the State Audit Office revealed shortcomings in financial resources totaling UAH 215.9 million, and in 2018 - more than UAH 305.8 million. state budget in the amount of more than 46.7 million UAH (in 2018 - 36.9 million UAH) and from local budgets over 47.2 million UAH (in 2018 - 22.9 million UAH). In 2019, the receipt of uncollected financial resources of budgets of all levels in the amount of UAH 108.7 million was ensured. The calculated value of the index of efficiency of management of budgetary offenses on establishment and compensation of material losses shows how many in monetary terms of the compensated losses account for $1 \mathrm{UAH}$ of the established material losses. Within the rights and powers granted by the State Audit Office in 2019, reimbursement and renewal of illegal, non-target expenditures and shortages of financial and material resources totaling almost UAH 466.6 million, which is $63.27 \%$ of such identified budget violations.

Key words: financial violations, time lag of financial violations, management efficiency.

Постановка проблеми у загальному вигляді та іï зв'язок 3 важливими науковими та практичними завданнями. У 2019 році загальна сума виявлених бюджетних порушень Держаудитслужбою, що призвели до втрат фінансових і матеріальних ресурсів бюджетів усіх рівнів та бюджетних установ - майже 952,7 млн грн, а у 2018 році - 1,1 млрд грн. Недотримання учасниками бюджетного процесу порядку складання, розгляду, затвердження, внесення змін, виконання бюджету чи звіту про виконання бюджету в регіонах України може призводити до зростання кількості бюджетних порушень та правопорушень відповідно. 
Аналіз останніх досліджень і публікацій, в яких започатковано вирішення проблеми. Закордонні та вітчизняні фахівці [1, с. 279-284, 2, с. 35-40, 3, с. 31-39, 4, с. 173-182] відзначають, що нецільове використання бюджетних коштів спостерігається майже у кожного розпорядника i набуває загрозливих масштабів для реалізації процесу фінансової децентралізації в регіонах України. Враховуючи небезпечність реалізації бюджетних порушень, правопорушень аналіз їх стану і ефективності управліннями ними в регіонах України є важливим.

Мета статті полягає в оцінці ефективності управління фінансовими санкціями за бюджетними порушеннями в регіонах України.

Виклад основного матеріалу дослідження 3 повним обгрунтуванням отриманих наукових результатів. Визначення методів оцінки бюджетних порушень сприятиме удосконаленню процесу їх аналізу та управління ними. А кваліфікація i класифікація бюджетних порушень дозволить визначити відповідні інструменти застосування фінансовий санкцій. Фінансові санкції є складовими процесу реалізації функцій, методів, інструментів управління бюджетними порушеннями Фінансові санкції застосовуються 3 метою спонукання правопорушника припинити здійснення бюджетного порушення чи покарати правопорушника.

Фінансові санкції - це засіб майнового впливу на правопорушника забезпечений примусовою силою держави, що застосовується у спеціальному процесуальному порядку уповноваженими на це державними органами та їх посадовими особами у випадку невиконання або неналежного виконання, а саме у випадку вчинення правопорушення суб'єктом господарювання - вимог законодавства про мобілізацію, розподіл, використання централізованих і децентралізованих фондів грошових коштів з метою відшкодування недоотриманих бюджетом та позабюджетними фондами грошових коштів, а також покарання порушників.

Фінансовим санкціям притаманні наступні особливості [5-8]: владний характер, це пов'язано з тим, що вони накладаються уповноваженими законом органами державної влади (державно-примусовий характер); формально визначені та поширюються на учасників бюджетних правовідносин за порушення та правопорушення; безпосередньо пов'язані 3 бюджетною відповідальністю та регулюються встановленими правовими нормами; застосовуються у випадку порушення приписів; не можуть бути встановлені угодою сторін; в окремих випадках вступають у дію за відсутності вини суб'єкта бюджетних правовідносин; застосовуються в судовому або позасудовому порядку, мають як каральний, так i правовідновлювальний характер; мають вираження у грошовій формі; вилучені кошти зараховуються до державного та місцевих грошових фондів, є додатковим обтяженням майнового характеру; мають порядок провадження щодо їх застосування, строки давності та специфіку доказу (пеня та штраф застосовуються у безспірному або судовому порядку); відрізняються від кримінальних, адміністративних, цивільно-правових як за змістом, так і за функціями застосування.

Фінансові санкції є засобом впливу на правопорушника, мають майновий характер, забезпечені примусовою силою держави. Фінансові санкції застосовуються у спеціальному порядку уповноваженими на це державними органами у випадку настання фінансової відповідальності. Фінансовим санкціям притаманне виключне грошове стягнення. Фінансові санкції відрізняються від кримінальних і адміністративних санкцій, оскільки мають право звернення до юридичних та фізичних осіб.

Фінансова санкція $є$ формою реагування держави на правопорушення у фінансовій і страховій діяльності є зовнішнім матеріальним вираженням державно-владного примусу за здійснення фінансового правопорушення.

Фінансові санкції залежно від охорони правовідносин поділяють на два види: правовідновлювальні (пеня), що реалізовує мотиваційну, компенсаційну, відновлювальну 
функції та каральні (штраф), що реалізовує каральну функцію управління фінансовими правопорушеннями.

Пеня, як фінансова санкція реалізується з метою усунення завданої шкоди внаслідок протиправних дій, примусового виконання невиконаних обов'язків. Основне призначення пені полягає у компенсації збитків.

Штрафні фінансові санкції мають на меті попередження правопорушення у фінансовій і страховій діяльності, а також на виправлення і перевиховання правопорушників. Штрафні фінансові санкції встановлюються за правопорушення у фінансовій і страховій діяльності $з$ метою покарання правопорушника, а також попередження нових правопорушень.

Залежно від видів бюджетних порушень (стаття 116 бюджетного кодексу), об'єктами порушень [5] є: порушення щодо складання фінансової звітності; порушення щодо використання бюджетних коштів; порушення процедури прийняття нормативно-правових актів про бюджет.

За суб’єктами, що застосовують фінансові санкції [5-10]: застосовуються судом, фіскальними органами, Національним банком України, фінансовою інспекцією тощо.

За суб'єктом бюджетного порушення, правопорушення: учасники бюджетного процесу, які порушують зобов'язання (юридичні та фізичні особи, які не виконують функцій у бюджетній системі або недостатньо їх виконують).

Залежно від різновидів нормативно-правових актів щодо управління бюджетними порушеннями та правопорушеннями [5-10]: такі, що містяться в кодексах та законах України та в підзаконних актах.

Залежно від визначеності розмірів покарання за бюджетними порушеннями, правопорушенням [4]: абсолютно визначені з чітким встановленням покарання - в неоподаткованих мінімумах доходів громадян, гривнях та відносно визначені, що передбачають мінімальний та максимальний розмір.

3 урахуванням способу призначення та пріоритету застосування фінансових санкцій за бюджетними порушеннями, правопорушенням [5-10]: основні та додаткові.

Фінансові санкції щодо бюджетних порушень, правопорушень застосовуються в судовому та позасудовому порядку.

Заходи державного примусу встановлюються до суб'єктів бюджетного порушення, правопорушення у разі їх вчинення для притягнення до фінансової відповідальності.

Примус передбачає настання для правопорушників негативних наслідків у вигляді обмежень особистого, організаційного або майнового характеру 3 метою їх покарання, запобіганню вчинення нових бюджетних правопорушень, спонукання дотримання правової поведінки.

До системи заходів державного примусу належать примусові та превентивні заходи: примусові заходи, що є реакцією держави на факт протиправної поведінки суб'єкта бюджетного порушення, правопорушення. Бюджетні порушення, правопорушення поділяються на припиняючі та превентивні заходи. Припиняючі заходи застосовують для припинення протиправних дій суб'єктів бюджетного правопорушення; превентивні заходи, які передують застосуванню санкцій для запобігання вчиненню бюджетного порушення, правопорушень, вчасне їх припинення та контроль.

Отже, фінансові санкції є важелем управління бюджетними правопорушеннями 3 використанням методу державного примусу з додатковими стягненнями у вигляді впливу на фінансовий стан порушника.

Поряд із фінансовими санкціями можуть застосовуватись адміністративні або кримінальні санкції, залежно від суспільної шкідливості або суспільної небезпеки відповідно. Адміністративні санкції таких особливостей не мають. Застосування фінансових санкцій несе негативні для суб'єкта порушення наслідки грошово-майнового впливу та на відміну від адміністративних санкцій, мають на меті покарання та компенсацію презумованої шкоди. 
Отже, реалізація фінансової санкції характеризується негативним аспектом щодо дотримання обов'язку, засудження протиправної дії рішенням компетентного органу, державний примус має несприятливі наслідки за порушення норм права.

Проведемо аналіз виявлених фінансових порушень Держаудитслужбою протягом 2018-2019 рр. за регіонами України [11].

В таблиці 1 проведемо оцінку кількості підприємств, установ та організацій, на яких виявлено порушення недоотримання фінансових ресурсів за регіонами та проаналізуємо темпи зміни цих показників і відсоток виявлених об'єктів контролю, де виявлено порушення, що призвели до втрат, у загальній кількості проведених ревізій у 2019 році.

Таблиця 1

Кількість підприємств, установ, організацій, на яких виявлено фінансові порушення в регіонах України у 2018-2019 pp. [11]

\begin{tabular}{|c|c|c|c|c|c|c|c|}
\hline \multirow[t]{2}{*}{ Регіон } & \multicolumn{3}{|c|}{$\begin{array}{c}\text { Кількість підприємств, установ, } \\
\text { організацій, на яких виявлено } \\
\text { недоотримання фінансових } \\
\text { ресурсів, одиниць }\end{array}$} & \multirow{2}{*}{$\begin{array}{c}\text { Проведено } \\
\text { перевірок, } \\
\text { одиниць }\end{array}$} & \multirow{2}{*}{$\begin{array}{c}\text { Проведено } \\
\text { ревізій, } \\
\text { одиниць }\end{array}$} & \multirow[t]{2}{*}{$\begin{array}{l}\text { Всього, } \\
\text { одиниць }\end{array}$} & \multirow[t]{2}{*}{$\begin{array}{c}\% \\
\text { виявлення } \\
\text { порушень }\end{array}$} \\
\hline & 2018 рік & 2019 рік & $\%$ & & & & \\
\hline Вінницька & 35 & 23 & 65,71 & 6 & 55 & 61 & 37,70 \\
\hline Волинська & 17 & 17 & 100,00 & 6 & 40 & 46 & 36,96 \\
\hline Дніпропетровська & 21 & 14 & 66,67 & 2 & 76 & 78 & 17,95 \\
\hline Донецька & 26 & 29 & 111,54 & 5 & 72 & 77 & 37,66 \\
\hline Житомирська & 27 & 23 & 85,19 & 9 & 51 & 60 & 38,33 \\
\hline Закарпатська & 31 & 22 & 70,97 & 3 & 44 & 47 & 46,81 \\
\hline Запорізька & 10 & 17 & 170,00 & 2 & 50 & 52 & 32,69 \\
\hline Івано-Франківська & 21 & 13 & 61,90 & 11 & 50 & 61 & 21,31 \\
\hline Кіровоградська & 19 & 10 & 52,63 & 3 & 33 & 36 & 27,78 \\
\hline Луганська & 13 & 9 & 69,23 & 6 & 33 & 39 & 23,08 \\
\hline Львівська & 48 & 25 & 52,08 & 12 & 91 & 103 & 24,27 \\
\hline Миколаївська & 14 & 16 & 114,29 & 2 & 42 & 44 & 36,36 \\
\hline Одеська & 47 & 36 & 76,60 & 3 & 84 & 87 & 41,38 \\
\hline Полтавська & 30 & 16 & 53,33 & 2 & 46 & 48 & 33,33 \\
\hline Рівненська & 21 & 15 & 71,43 & 1 & 35 & 36 & 41,67 \\
\hline Сумська & 20 & 8 & 40,00 & 4 & 33 & 37 & 21,62 \\
\hline Тернопільська & 19 & 27 & 142,11 & 7 & 45 & 52 & 51,92 \\
\hline Харківська & 55 & 31 & 56,36 & 8 & 91 & 99 & 31,31 \\
\hline Херсонська & 26 & 11 & 42,31 & 2 & 43 & 45 & 24,44 \\
\hline Хмельницька & 18 & 15 & 83,33 & 2 & 40 & 42 & 35,71 \\
\hline Черкаська & 35 & 15 & 42,86 & 6 & 52 & 58 & 25,86 \\
\hline Чернівецька & 17 & 9 & 52,94 & 2 & 29 & 31 & 29,03 \\
\hline Чернігівська & 28 & 45 & 160,71 & 1 & 72 & 73 & 61,64 \\
\hline м. Київ та область & 63 & 43 & 68,25 & 4 & 145 & 149 & 28,86 \\
\hline Всього & 661 & 489 & 73,98 & 109 & 1352 & 1461 & 33,47 \\
\hline Держаудитслужба & 17 & 13 & 76,47 & 9 & 40 & 49 & 26,53 \\
\hline Разом & 678 & 502 & 74,04 & 118 & 1392 & 1510 & 33,25 \\
\hline
\end{tabular}

У 2019 році у порівнянні з 2018 роком найбільшу кількість підприємств, установ, організацій, на яких виявлено недоотримання фінансових ресурсів виявлено Держаудитслужбою у Запорізькій області - зростання в 1,7 рази (або на 7 одиниць); Чернігівській області - зростання у 1,6 рази (або на 17 одиниць), Тернопільській області зростання 1,4 рази (або на 8 одиниць); Миколаївській області - в 1,14 рази (або на 2 одиниці); в Донецькій області - зростання 1,11 рази (або на 3 одиниці). Найменшу ж кількість підприємств, установ, організацій, на яких виявлено недоотримання фінансових ресурсів спостерігалось у Сумській області - на 40\%, або 12 одиниць; Херсонській та Черкаській областях - на 42,3 та 42,8\% відповідно. 
В цілому у 2019 році на 502 об'єктах контролю Держаудитслужби виявлено недоотримання фінансових ресурсів бюджетами на загальну суму 215,9 млн грн, а у 2018 році - понад 305,8 млн грн [11].

Проведемо оцінку встановлених сум фінансових порушень за бюджетними правопорушеннями, що призвели до незаконних, нецільових витрат та недостачі ресурсів у 2018-2019 рр. у таблиці 2.

Таблиця 2

Оцінка виявлення та забезпечення усунення бюджетних порушень, пов'язаних 3 недоотриманням фінансових ресурсів в регіонах України у 2018-2019 рр. [11]

\begin{tabular}{|c|c|c|c|c|c|c|c|}
\hline \multirow[t]{2}{*}{ Регіон } & \multicolumn{3}{|c|}{$\begin{array}{c}\text { Виявлено недоотримання } \\
\text { фінансових ресурсів до бюджетів, } \\
\text { тис. грн } \\
\end{array}$} & \multicolumn{2}{|c|}{$\begin{array}{c}\text { Надійшло фінансових } \\
\text { ресурсів до бюджетів, } \\
\text { тис. грн }\end{array}$} & \multicolumn{2}{|c|}{$\begin{array}{c}\text { Надходження } \\
\text { фінансових ресурсів } \\
\text { до бюджетів, \% }\end{array}$} \\
\hline & 2018 рік & 2019 рік & $\%$ & 2018 рік & 2019 рік & 2018 рік & 2019 рік \\
\hline Вінницька & 4203,08 & 1212,56 & 28,85 & 4066,64 & 2250,84 & 96,75 & 185,63 \\
\hline Волинська & 3126,27 & 483,66 & 15,47 & 1297,85 & 252,51 & 41,51 & 52,21 \\
\hline Дніпропетровська & 2966,05 & 9441,24 & 318,31 & 7052,69 & 3328,70 & 237,78 & 35,26 \\
\hline Донецька & 3274,79 & 3222,67 & 98,41 & 2136,66 & 1918,74 & 65,25 & 59,54 \\
\hline Житомирська & 4166,63 & 3571,71 & 85,72 & 3946,97 & 3712,10 & 94,73 & 103,93 \\
\hline Закарпатська & 2877,12 & 3619,39 & 125,8 & 1404,06 & 1985,29 & 48,8 & 54,85 \\
\hline Запорізька & 1176,58 & 11184,63 & 950,61 & 4682,70 & 8360,35 & 397,99 & 74,75 \\
\hline Івано-Франківська & 6854,61 & 5549,41 & 80,96 & 3788,78 & 8642,05 & 55,27 & 155,73 \\
\hline Кіровоградська & 5315,36 & 1317,61 & 24,79 & 4084,41 & 1086,18 & 76,84 & 82,44 \\
\hline Луганська & 1160,89 & 128,79 & 11,09 & 294,21 & 976,35 & 25,34 & 758,09 \\
\hline Львівська & 5905,51 & 2262,20 & 38,31 & 9092,63 & 2310,05 & 153,97 & 102,12 \\
\hline Миколаївська & 3833,24 & 16907,61 & 441,08 & 19428,37 & 2258,83 & 506,84 & 13,36 \\
\hline Одеська & 128603,26 & 44842,28 & 34,87 & 119745,06 & 19427,22 & 93,11 & 43,32 \\
\hline Полтавська & 2010,78 & 1262,81 & 62,8 & 3648,36 & 5065,69 & 181,44 & 401,14 \\
\hline Рівненська & 2800,02 & 3572,76 & 127,6 & 3931,26 & 3274,46 & 140,4 & 91,65 \\
\hline Сумська & 11271,60 & 415,51 & 3,69 & 4081,58 & 4639,76 & 36,21 & 1116,64 \\
\hline Тернопільська & 7983,79 & 13856,44 & 173,56 & 7618,95 & 2799,50 & 95,43 & 20,2 \\
\hline Харківська & 3265,78 & 7763,76 & 237,73 & 3463,49 & 3323,95 & 106,05 & 42,81 \\
\hline Херсонська & 2443,39 & 1374,15 & 56,24 & 1205,78 & 2189,99 & 49,35 & 159,37 \\
\hline Хмельницька & 1172,95 & 3361,42 & 286,58 & 2038,47 & 4700,11 & 173,79 & 139,83 \\
\hline Черкаська & 7079,77 & 2191,35 & 30,95 & 2804,45 & 1327,24 & 39,61 & 60,57 \\
\hline Чернівецька & 2156,70 & 570 & 26,43 & 976,08 & 372,8 & 45,26 & 65,4 \\
\hline Чернігівська & 4279,10 & 10028,79 & 234,37 & 1619,53 & 8769,36 & 37,85 & 87,44 \\
\hline м. Київ та область & 84440,13 & 49396,24 & 58,5 & 13090,82 & 13242,72 & 15,5 & 26,81 \\
\hline Всього & 302367,40 & 197536,99 & 65,33 & 225499,80 & 106214,79 & 74,58 & 53,77 \\
\hline Держаудитслужба & 3467,43 & 18336,76 & 528,83 & 863,09 & 2493,95 & 24,89 & 13,6 \\
\hline Разом & 305834,83 & 215873,75 & 70,59 & 226362,89 & 108708,74 & 74,01 & 50,36 \\
\hline
\end{tabular}

Найвище значення виявлених бюджетних порушень у регіонах України у 2019 році у порівнянні до 2018 року мали Запорізька область - зростання у 9,5 разів або на 10 008,05 тис. грн; Миколаївська область - зростання у 4,4 рази або на 13 074,37 тис. грн; Дніпропетровська область - зростання у 3,2 рази або на 6475,19 тис. грн; Хмельницька область - зростання у 2,8 рази або на 2 188,47 тис. грн.

Найнижчі значення виявлених бюджетних порушень у регіонах України у 2019 році у порівнянні до 2018 року мали Сумська область - зниження на 96,4\% або на -10 856,09 тис. грн; Луганська область - зниження на 88,9\% або на -1 032,10 тис. грн; Волинська область зниження на 84,5\% або на -2 642,61 тис. грн; Черкаська область - зниження на 70\% або на -4 888,42 тис. грн.

Каральні функції управління бюджетними порушеннями існують паралельно 3 правовідновлювальними, оскільки для держави важливим $є$ не тільки покарати порушника, а й відновити публічні майнові інтереси, компенсувати збитки від такого правопорушення. 
Саме тому доцільно здійснювати порівняння обсягів надходжень фінансових ресурсів до бюджетів і виявлених недоотриманих ресурсів. У 2018 році: Вінницька, Дніпропетровська, Житомирська, Запорізька, Львівська, Миколаївська, Одеська, Полтавська, Рівненська, Харківська, Хмельницька області, а у 2019 році: Вінницька, Житомирська, Івано-Франківська, Луганська, Львівська, Полтавська, Сумська, Херсонська, Хмельницька області за результатами виявлених на та нарахованих недоотриманих фінансових ресурсів до бюджету забезпечили їх надходження в повному обсязі. Іншим регіонам не вдавалось забезпечити надходження виявлених недоотриманих фінансових ресурсів за бюджетними порушеннями протягом досліджуваного періоду. Це пов'язано із проведенням досудових розслідувань, застосування фінансових санкцій, їх призупинення, зупинення операцій з бюджетними коштами, зменшення бюджетних призначень/асигнувань, пред’явлення позовів до суду тощо.

В цілому, за результатами проведеної органами Держаудитслужби роботи у 2019 році забезпечено надходження недоотриманих фінансових ресурсів до бюджетів всіх рівнів - 108,7 млн грн, а у 2018 році - 226,4 млн грн, що в 2,1 рази менше [11].

Оцінимо процес виявлення та забезпечення усунення бюджетних порушень, що призвели до незаконних, нецільових витрат та недостач в регіонах України у 2018-2019 рр. в таблиці 3.

Таблиця 3

Оцінка виявлення та забезпечення усунення бюджетних порушень, що призвели до незаконних, нецільових витрат та недостач в регіонах України у 2018-2019 pp. [11]

\begin{tabular}{|c|c|c|c|c|c|c|c|}
\hline \multirow[t]{2}{*}{ Регіон } & \multicolumn{3}{|c|}{$\begin{array}{c}\text { Виявлено бюджетні } \\
\text { порушення, що призвели до } \\
\text { протиправних, нецільових } \\
\text { витрат та недостач ресурсів, } \\
\text { тис. грн }\end{array}$} & \multicolumn{2}{|c|}{$\begin{array}{c}\text { Відшкодовано за } \\
\text { бюджетними } \\
\text { порушеннями, тис. грн }\end{array}$} & \multicolumn{2}{|c|}{$\begin{array}{c}\text { Управління } \\
\text { фінансовими } \\
\text { порушеннями, \% }\end{array}$} \\
\hline & 2018 рік & 2019 рік & $\%$ & 2018 рік & 2019 рік & 2018 рік & 2019 рік \\
\hline Вінницька & 25130,28 & 25164,41 & 100,14 & 16606,71 & 28930,39 & 66,08 & 114,97 \\
\hline Волинська & 33068,89 & 15298,62 & 46,26 & 24376,10 & 18320,32 & 73,71 & 119,75 \\
\hline Дніпропетровська & 47314,07 & 52131,01 & 110,18 & 34650,33 & 18427,44 & 73,23 & 35,35 \\
\hline Донецька & 19719,88 & 17266,65 & 87,56 & 16431,78 & 18082,07 & 83,33 & 104,72 \\
\hline Житомирська & 20340,37 & 10353,15 & 50,9 & 15600,87 & 13217,52 & 76,7 & 127,67 \\
\hline Закарпатська & 15884,94 & 7115,25 & 44,79 & 11273,03 & 3804,31 & 70,97 & 53,47 \\
\hline Запорізька & 33066,20 & 38005,61 & 114,94 & 26764,56 & 12757,72 & 80,94 & 33,57 \\
\hline Івано-Франківська & 15622,75 & 20559,92 & 131,6 & 13769,40 & 17893,31 & 88,14 & 87,03 \\
\hline Кіровоградська & 22996,65 & 15451,21 & 67,19 & 18333,32 & 12227,63 & 79,72 & 79,14 \\
\hline Луганська & 15362,41 & 29842,30 & 194,26 & 15679,15 & 12336,44 & 102,06 & 41,34 \\
\hline Львівська & 51167,26 & 47882,88 & 93,58 & 36253,94 & 42955,33 & 70,85 & 89,71 \\
\hline Миколаївська & 42685,35 & 43613,41 & 102,17 & 20297,97 & 20344,45 & 47,55 & 46,65 \\
\hline Одеська & 58979,14 & 93655,17 & 158,79 & 47541,66 & 41797,62 & 80,61 & 44,63 \\
\hline Полтавська & 22317,41 & 14618,49 & 65,5 & 20479,78 & 14217,49 & 91,77 & 97,26 \\
\hline Рівненська & 21200,34 & 9564,65 & 45,12 & 13429,54 & 6454,76 & 63,35 & 67,49 \\
\hline Сумська & 6825,80 & 3549,60 & 52 & 8077,53 & 2865,57 & 118,34 & 80,73 \\
\hline Тернопільська & 24670,42 & 26293,12 & 106,58 & 16448,79 & 26581,01 & 66,67 & 101,09 \\
\hline Харківська & 69137,72 & 40625,81 & 58,76 & 26122,26 & 16134,79 & 37,78 & 39,72 \\
\hline Херсонська & 37686,06 & 24685,30 & 65,5 & 41219,38 & 18388,72 & 109,38 & 74,49 \\
\hline Хмельницька & 25541,74 & 13483,91 & 52,79 & 20308,77 & 7896,77 & 79,51 & 58,56 \\
\hline Черкаська & 30951,35 & 49892,89 & 161,2 & 36375,18 & 36295,04 & 117,52 & 72,75 \\
\hline Чернівецька & 19390,08 & 9796,50 & 50,52 & 14449,48 & 10656,29 & 74,52 & 108,78 \\
\hline Чернігівська & 30810,61 & 35191,98 & 114,22 & 20211,03 & 17253,73 & 65,6 & 49,03 \\
\hline м. Київ та область & 59700,17 & 68542,46 & 114,81 & 32404,13 & 31646,66 & 54,28 & 46,17 \\
\hline Всього & 749569,89 & 712584,30 & 95,07 & 547104,69 & 449485,37 & 72,99 & 63,08 \\
\hline Держаудитслужба & 38561,03 & 24239,32 & 62,86 & 26808,45 & 16723,81 & 69,52 & 68,99 \\
\hline Разом & 788130,92 & 736823,62 & 93,49 & 573913,14 & 466209,18 & 72,82 & 63,27 \\
\hline
\end{tabular}


Найвищих значень нарахування штрафних санкцій за встановленими бюджетними порушеннями у регіонах України у 2019 році у порівнянні до 2018 року мали: Луганська область - зростання в 1,9 рази або на 14 479,89 тис. грн. (; Одеська область - зростання у 1,6 рази або на 34 676,03 тис. грн; Черкаська область - зростання у 1,6 рази або на 18 941,54 тис. грн.

Найнижчих значень нарахування штрафних санкцій за встановленими бюджетними порушеннями у регіонах України у 2019 році у порівнянні до 2018 року мали: Закарпатська область - зниження на 56\% або на 8 769,69 тис. грн; Волинська область - зниження на 54\% або на 17 770,27 тис. грн; Рівненська область - зниження на 55\% або на 11 635,69 тис. грн.

Розглянемо ефективність управління фінансовими санкціями за бюджетними порушеннями шляхом порівняння обсягів виявлених недоотриманих до відшкодованих фінансових ресурсів за бюджетними порушеннями. Високий рівень ефективності досягнення правовідновлювальної функції фінансових санкцій за бюджетними порушеннями буде таким, якщо відсоток виконання виявлених до відшкодованих штрафним санкцій дорівнюватиме 100\%. Так, у 2018 році ефективним процес управління бюджетними порушеннями в частині нарахування та стягнення фінансових санкцій відслідковувався у Луганській (102,06\%), Сумській (118,34\%), Херсонській (109,38\%), Черкаській $(117,52 \%)$ областях (збільшення зростання обсягів відшкодувань відбувалось за бюджетними порушеннями, що виявлені у попередніх звітних періодах), а в інших регіонах - недостатньо ефективний. А Вже у 2019 році ефективним процес управління бюджетними порушеннями в частині нарахування та стягнення фінансових санкцій відслідковувався у Вінницькій $(114,97 \%)$, Волинській (119,75\%), Донецькій (104,72\%), Житомирській (127,67\%), Тернопільській $(101,09 \%)$, Чернівецькій $(108,78 \%)$ областях (збільшення обсягів відшкодувань відбувалось за бюджетними порушеннями, що виявлені у попередніх звітних періодах), в той час як в інших регіонах України процес стягнення фінансових санкцій відбувався недостатньо ефективно.

Отже, в 2019 році не за цільовим призначенням проведено витрати державних ресурсів 3 державного бюджету на суму більш понад 46,7 млн грн, (у 2018 році - 36,9 млн грн) та 3 місцевих бюджетів понад 47,2 млн грн (у 2018 році - 22,9 млн грн). І забезпечено надходження у 2019 році недоотриманих фінансових ресурсів бюджетів всіх рівнів у обсязі 108,7 млн грн [11].

У межах прав та наданих повноважень органами Держаудитслужби у 2019 році забезпечено відшкодування і поновлення незаконних, нецільових витрат та недостач фінансових і матеріальних ресурсів на загальну суму майже 466,6 млн грн, що становить 63,27\% від виявлених таких бюджетних порушень [11].

При оцінці індексу ефективності управління бюджетними порушеннями відшкодування до встановленої суми збитків слід враховувати і значення часового лагу, який відображає відставання або випередження у часі одного відшкодування збитків порівняно $з$ встановленими сумами матеріальної шкоди. В цілому, вони свідчитимуть про ефективність правоохоронних заходів із протидії бюджетних порушень, але слід враховувати і вплив суб'єктивних факторів, пов'язаними 3 ним явищем. Повний лаг бюджетних порушень складатиметься $з$ двох частин: оперативний лаг - період часу, необхідний для встановлення суми матеріальних збитків від вчинених бюджетних порушень, тобто від настання правочинності процесу забезпечення відшкодування [2, с. 38].

Висновки. Проведений управлінський аналіз бюджетних порушень в регіонах України дозволив отримати кількісну характеристику їх стану, рівня, структури, динаміки, форм стягнення. Це сприяло виявленню статистичних зв'язків, залежностей, співвідношень, закономірностей бюджетних порушень, формування напрямів удосконалення управління ними. Подальші дослідження вирішення проблем розвитку управління бюджетними порушеннями важливо розглядати в контексті напрямів розвитку стратегії протидії відмиванню доходів, здобутих протиправним шляхом, наявних проблем регіонального 
розвитку України та можливостей активізації процесу управління бюджетними порушеннями.

\section{Список бібліографічного опису}

1. Vatslavskyi, O. (2016). Question Of Improvement Of Budget Control At The Local Level. Baltic Journal of Economic Studies, 2(5), 35-40. https://doi.org/10.30525/2256-0742/2016-2-5-35-40.

2.Вавдіюк, Н. С. Управлінський аналіз фінансових правопорушень. Економічні науки. Серія : Економіка та менеджмент. 2018. Вип. 15. С. 31-39. URL: http://nbuv.gov.ua/UJRN/ecnem_2018_15_6(дата звернення: 14.12.2020).

3. Voznyak, Halyna violations and abuses in the management of financial resources at the local level in conditions of decentralization). Economic Journal of Lesia Ukrainka Eastern European National University. Vol 1. No 21. 2020. P. 173-182. https://doi.org/10.29038/2411-4014-2020-01-173-181.

4.Базярук I. М. Економічна злочинність та ії ознаки. Науковий вісник Львівського держсавного університету внутрішніх справ. Сер. юридична. Вип. 2. 2008. С. 279-284.

5.Бюджетний кодекс України : Відомості Верховної Ради України (BBP), 2010, № 50-51, ст.572. URL: https://zakon.rada.gov.ua/laws/show/2456-17/ed20150920\#Text (дата звернення: 12.12.2020).

6.Коментар до законодавства про фінансово-правові санкції. К.: Юрінком Інтер, 2007. 416 с.

7. Принципи та функції фінансового права. URL: https://pidruchniki.com/16280414/pravo/printsipi_funktsiyi_finansovogo_prava (дата звернення: 14.12.2020).

8.Співвідношення фінансово-правової відповідальності та фінансових санкцій. URL: https://pravoua.com.ua/ua/store/ pravoukr/pravo_ukr_7_ukr/Zanfirov_7_12/(дата звернення: 14.12.2020).

9.Кодекс України про адміністративні правопорушення від 07.12.1984 p. № 8073-1- X. URL: https://zakon.rada.gov.ua/ laws/main/80731-10 (дата звернення: 14.12.2020).

10. Кримінальний кодекс України від 05.04.2001 p. № 2341-III. URL: https://zakon.rada.gov.ua/laws/show/2341-14 (дата звернення: 14.12.2020).

11. Статистичні звіти Державної аудиторської служби України. URL: https:/www.dasu.gov.ua/ua/plugins/userPages/53 (дата звернення: 14.12.2020).

\section{References}

1.Vatslavskyi, O. (2016). Question Of Improvement Of Budget Control At The Local Level. Baltic Journal of Economic Studies, 2(5), 35-40. https://doi.org/10.30525/2256-0742/2016-2-5-35-40.

2.Vavdiyuk, N. S. Upravlins'kyy analiz finansovykh pravoporushen'. Ekonomichni nauky. Seriya : Ekonomika ta menedzhment. 2018. Vyp. 15. S. 31-39.URL: http://nbuv.gov.ua/UJRN/ecnem_2018_15_6. [in Ukrainian].

3. Voznyak, Halyna violations and abuses in the management of financial resources at the local level in conditions of decentralization). Economic Journal of Lesia Ukrainka Eastern European National University. Vol 1. No 21. 2020. P. 173-182. https://doi.org/10.29038/2411-4014-2020-01-173-181.

4.Bazyaruk I. M. Ekonomichna zlochynnist' ta yiyi oznaky. Naukovyy visnyk L'vivs'koho derzhavnoho universytetu vnutrishnikh sprav. Ser. yurydychna. Vyp. 2. 2008. S. 279-284. [in Ukrainian].

5. Byudzhetnyy kodeks Ukrayiny : Vidomosti Verkhovnoyi Rady Ukrayiny (VVR), 2010, № 50-51, st.572. URL: https://zakon.rada.gov.ua/laws/show/2456-17/ed20150920\#Text. [in Ukrainian].

6. Komentar do zakonodavstva pro finansovo-pravovi sanktsiyi. K.: Yurinkom Inter, 2007. 416 s. [in Ukrainian].

$\begin{array}{lllll}\text { 7. Pryntsypy ta funktsiyi } & \text { finansovoho } & \text { unL: }\end{array}$ https://pidruchniki.com/16280414/pravo/printsipi_funktsiyi_finansovogo_prava. [in Ukrainian].

8. Spivvidnoshennya finansovo-pravovoyi vidpovidal'nosti ta finansovykh sanktsiy. URL: https://pravoua.com.ua/ua/store/ pravoukr/pravo_ukr_7_ukr/Zanfirov_7_12/ [in Ukrainian].

9. Kodeks Ukrayiny pro administratyvni pravoporushennya vid 07.12.1984 r. № 8073-1- X. URL: https://zakon.rada.gov.ua/ laws/main/80731-10. [in Ukrainian].

10. Kryminal'nyy kodeks Ukrayiny vid 05.04.2001 r. № 2341-III. URL: https://zakon.rada.gov.ua/laws/show/2341-14. [in Ukrainian].

11. Statystychni zvity Derzhavnoyi audytors'koyi sluzhby Ukrayiny. URL: https://www.dasu.gov.ua/ua/plugins/userPages/53. [in Ukrainian].

Дата подання публікації 20.12.2020 p. 